\title{
Comparative Zooplanktonic Diversity with Respect to Physicochemical Parameters of Saraswati and Shingoda Rivers of Gujarat, India
}

\author{
Jatin V. Raval'*, Agni Vyas', Nikul Chavda', \\ Suhas Vyas ${ }^{1}$ \\ 'Department of Life Sciences, Bhakta Kavi Narsinh Mehta \\ University, Junagadh, Gujarat, India \\ ${ }^{2}$ Shri Mahila Arts and Science College, Simar, India \\ Study Area: Gir-Somnath, Gujrat, India \\ Coordinates: $20^{\circ} 55^{\prime} 13.42 " \mathrm{~N} ; 70^{\circ} 36^{\prime} 39.64 " \mathrm{E}$
}

Keywords: Limnology, Phytoplankton

\section{Abstract}

Zooplanktons are bio-indicators of water ecosystems. Their diversity depends on the water condition. In the present study, samples were collected from the six different locations of two Rivers namely; Saraswati and Shingoda for the study of zooplankton diversity. These rivers are located in Gir-Somnath district of Gujarat. The entire work was carried out during the winter season and the effort was being made to analyze the diversity of Zooplankton in different selected sites to compare the diversity found in both the rivers. During the survey 14 physicochemical parameters of water like $\mathrm{pH}$, Electric conductivity, DO, BOD, TS, TDS, TSS, Total Hardness, $\mathrm{Ca}^{++}$Hardness, $\mathrm{Mg}^{+}$ Hardness, Alkalinity, Acidity, Salinity, and Chlorinity were also analyzed. Total 16 species of zooplankton were recorded among which Acrocalanus gracilis, Calanopia minor, Centropages tenuiremis, Copepod nauplii, Tortanus barbatus, Pseudodiaptomus serricaudatus and Tortanus forcipatus were the most dominant zooplankton.

2017). They are primary producers in aquatic habitat and form the first trophic level in the food web. They are also a food source for other aquatic organisms. Zooplanktons also play an important role in the food chain as they are second in trophic level as primary consumers and consumes phytoplankton, and also contribute to the next trophic level (Sharma et al., 2013). Zooplanktons have been considered to be the ecological indicators of water bodies (Gajbhiye \& Desai, 1981; Roy et al., 2015) and their biomass, abundance and species diversity have been used to determine the quality of the aquatic environment (Roy et al., 2015). The planktonic forms are represented by Protozoa, Arthropoda, Rotifera and they are dominating the planktonic diversity (Sharma \& Mankodi, 2011). Zooplankton is classified under the following classes: Protozoa, Copepoda, Rotifera, Cladocera and Ostracoda (Rice et al., 2012). Planktonic communities are influenced by the prevailing physicochemical parameters and these determine their abundance, occurrence and seasonal variations (Singh, 2015).

Wetlands or Rivers harbour a rich biological diversity, provide sustenance for millions of people and face ongoing threats as results of human activities throughout the world (Balcer et al., 1984).

Gujarat is the seventh largest state of India by its 
geographical area. It comprises three different geographic regions. South Gujarat, North \& Central Gujarat and Saurashtra \& Kutch. Larger area of Gujarat is arid, semi-arid \& water scarcity prone zone (Goswami \& Mankodi, 2012). Gir-Somnath is a district of Gujarat which enjoys an average annual rainfall of $669 \mathrm{~mm}$ (Shah, 2017). Saraswati and Shingoda Rivers are very important rivers of Gir-Somnath district and they contain water more than six to seven and eight to ten months in a year respectively which supply water for the potable and agricultural purpose to adjoining villages. Saraswati River and Shingoda River both originate from two different places but meet in the Arabian Sea at Triveni Sangam-Somnath.

In this study, two samples were collected from upstream, two samples from midstream and two samples from downstream from Shingoda and Saraswati River. A total of twelve samples were collected from these rivers, fourteen physicochemical parameters were analyzed and planktonic diversity was investigated.

\section{Materials and methods:}

Study area: six-sample collection points were selected from River Saraswati and Shingoda (sampling sites). Samples were collected from suitable depth in the water column from the water surface. GPS locations of sampling sites were noted down (Table-1). Water samples were collected in a plastic bottle (non-metallic, free-flushing sample recommended for the same).

Table 1.sampling sites and GPS Location

\begin{tabular}{|c|c|c|c|}
\hline \multicolumn{2}{|c|}{ No. Stream } & Sites:Village name & GPS Location \\
\hline \multicolumn{4}{|c|}{ Saraswati River } \\
\hline 1 & Upstream & $\begin{array}{l}\text { 1:Rasulpara } \\
\text { 2:Jambur }\end{array}$ & $\begin{array}{l}21^{\circ} 5^{\prime} 32.39^{\prime \prime} \mathrm{N}_{70}^{\circ} 39^{\prime} 20.38^{\prime \prime E} \\
21^{\circ} 1^{\prime} 57.72^{\prime \prime N} 70^{\circ} 36^{\prime} 19.13 " 13^{\prime \prime E}\end{array}$ \\
\hline 2 & Midstream & $\begin{array}{l}\text { 3:Bhimdevad } \\
4: \text { Prachi }\end{array}$ & $\begin{array}{l}20^{\circ} 5^{\prime} 16.15^{\prime \prime} \mathrm{N}_{70}{ }^{\circ} 36^{\prime} 47.47^{\prime \prime} \mathrm{E} \\
20^{\circ} 55^{\prime} 13.42^{\prime \prime} \mathrm{N}_{70}{ }^{\circ} 6^{\prime} 39.64^{\prime \prime} \mathrm{E}\end{array}$ \\
\hline 3 & Downstream & $\begin{array}{l}\text { 5:Umbari } \\
\text { 6:Triveni-Sangan }\end{array}$ & $\begin{array}{l}20^{\circ} 54^{\prime} 4.88^{\prime \prime N} 70^{\circ} 31^{\prime} 31.27^{\prime \prime} \mathrm{E} \\
20^{\circ} 52^{\prime} 52.72^{\prime \prime N} 70^{\circ} 25^{\prime} 10.41^{\prime \prime E}\end{array}$ \\
\hline \multicolumn{4}{|c|}{ Shingoda River } \\
\hline 1 & Upstream & $\begin{array}{l}\text { 1:Jamvala } \\
\text { 2:Jamjir }\end{array}$ & $\begin{array}{l}21^{\circ} 1^{\prime} 16.09 " \mathrm{~N} 70^{\circ} 46^{\prime} 34.05^{\prime \prime E} \\
20^{\circ} 57^{\prime} 51.43^{\prime \prime} 0^{\circ} 45^{\prime} 56.27 " \mathrm{E}\end{array}$ \\
\hline 2 & Midstream & $\begin{array}{l}\text { 3:Ghantvad } \\
\text { 4:Chhachhar }\end{array}$ & $\begin{array}{l}20^{\circ} 55^{\prime} 57.31^{\prime \prime N} 70^{\circ} 45^{\prime} 38.18^{\prime \prime E} \\
20^{\circ}{ }^{\prime} 48.04 "{ }^{\prime} 0^{\circ} 45^{\prime} 24.088^{\prime \prime E}\end{array}$ \\
\hline 3 & Downstream & $\begin{array}{l}\text { 5:Kodinar } \\
\text { 6:Mul Dwarka }\end{array}$ & $\begin{array}{l}20^{\circ} 47^{\prime} 41.60^{\prime \prime} \mathrm{N}_{70}^{\circ} 41^{\prime} 56.95^{\prime \prime E} \\
20^{\circ} 45^{\prime} 44.30^{\prime \prime} \mathrm{N}_{70}^{\circ} 40^{\prime} 21.40^{\prime \prime} \mathrm{E} \\
\end{array}$ \\
\hline
\end{tabular}

The Standard method was used for water collection and analysis. For plankton diversity, plankton net was used. For Sample collection and analysis of water sample, various methods used are given ahead.

Three liters of water samples were collected from each site for physicochemical analysis, approximately from less than 1.5 feet of river water surface. Time of water collection and temperature of water were measured at the field site and transferred the preserved samples to the laboratory as soon as possible for further testing. The average temperature range was recorded between $18^{\circ} \mathrm{C}$ to $30^{\circ} \mathrm{C}$ at each site (winter period).

Sample Collection for Zooplankton Analysis: the zooplankton samples were collected by filtering 6 Litre water through plankton net of $20 \mu \mathrm{m}$ mesh size of filtering cloth and concentrated up to $100 \mathrm{ml}$. The concentrated zooplankton sample was preserved immediately with the help of $4 \%$ formaldehyde for $48 \mathrm{hrs}$, and further incubation drop count Method was used for identification of plankton diversity (Chavda et al., 2017). The samples were analyzed qualitatively under the Compound microscope and Light microscope for the study of different types of zooplankton (Goswami \& Mankodi, 2012).

Physico-Chemical Parameters: a total of 14 physicochemical parameters of these collected water samples were analyzed. These parameters include; $\mathrm{pH}, \mathrm{EC}, \mathrm{TS}$, TDS, TSS, DO, BOD, Total Hardness, Ca++ hardness, Mg++ hardness, Acidity, Alkalinity, Salinity, Chlorinity (Chavda et al., 2018). All the analysis were done by following common prescribed methods.

\section{Results and Discussion:}

Rivers are great ecosystems and it supports a great biodiversity. In the present research work we have investigated interactions between physicochemical parameters with their impact on planktonic biodiversity during winter time period of 2018. The quality of River water is generally governed by some physico-chemical and biological parameters. Table-2a Shows physico-chemical parameters of Saraswati River and table $2 \mathrm{~b}$ shows physicochemical parameters of Shingoda River.

Table -2a: Physico-Chemical Parameters of Saraswati River

\begin{tabular}{|c|c|c|c|c|c|c|c|}
\hline \multicolumn{2}{|c|}{ No.Parameters } & \multirow{3}{*}{$\begin{array}{l}1 \\
7: 15 \\
\text { am }\end{array}$} & \multirow{2}{*}{$\frac{2}{8: 13}$} & \multirow{2}{*}{$\frac{3}{9: 45}$} & \multirow{2}{*}{$\frac{4}{10: 48}$} & \multirow{2}{*}{$\frac{5}{3: 18}$} & \multirow{2}{*}{$\frac{6}{4: 14}$} \\
\hline 1 & Time & & & & & & \\
\hline & & & $\mathrm{am}$ & $\mathrm{am}$ & $\mathrm{am}$ & $\mathrm{pm}$ & $\mathrm{pm}$ \\
\hline 2 & Temperature & $19^{\circ} \mathrm{C}$ & $20^{\circ} \mathrm{C}$ & $21^{\circ} \mathrm{C}$ & $23^{\circ} \mathrm{C}$ & $30^{\circ} \mathrm{C}$ & $30^{\circ} \mathrm{C}$ \\
\hline 3 & $\mathrm{pH}$ & 8.89 & 8.38 & 8.46 & 8.29 & 8.34 & 8.95 \\
\hline 4 & $\begin{array}{l}\text { Conductivity } \\
(\mu \mathrm{s} / \mathrm{cm})\end{array}$ & 0.11 & 0.41 & 0.21 & 0.36 & 0.16 & 2.02 \\
\hline 5 & $\mathrm{DO}(\mathrm{mg} / \mathrm{L})$ & 5.1 & $4 \cdot 3$ & $5 \cdot 5$ & 5 & 6.3 & 6 \\
\hline 6 & $\mathrm{BOD}(\mathrm{mg} / \mathrm{L})$ & 1.75 & 1.65 & 1.65 & 1.6 & 1.3 & 1.6 \\
\hline 7 & $\mathrm{TS}(\mathrm{mg} / \mathrm{L})$ & 733.2 & 703.2 & 451.6 & 492.6 & 295.6 & 891 \\
\hline 8 & TDS (mg/L) & 680 & 654 & 398 & 445 & 250 & 841 \\
\hline 9 & TSS (mg/L) & 53.2 & 49.6 & 53.6 & $47 \cdot 6$ & 45.6 & 50 \\
\hline 10 & $\begin{array}{l}\text { Total Hardness } \\
(\mathrm{mg} / \mathrm{L})\end{array}$ & 192 & 236 & 184 & 152 & 212 & 364 \\
\hline 11 & $\begin{array}{l}\text { Ca++ Hardness } \\
(\mathrm{mg} / \mathrm{L})\end{array}$ & 32 & 208 & 44 & 96 & 168 & 172 \\
\hline 12 & $\begin{array}{l}\text { Mg+ Hardness } \\
(\mathrm{mg} / \mathrm{L})\end{array}$ & 160 & 28 & 140 & 56 & 44 & 192 \\
\hline 13 & Salinity (mg/L) & 32.98 & $25 \cdot 55$ & 20.60 & 19.78 & $17 \cdot 99$ & $55 \cdot 98$ \\
\hline 14 & Alkalinity (mg/L) & 780 & 730 & 760 & 750 & 780 & 830 \\
\hline 15 & Acidity (mg/L) & 250 & 200 & 220 & 240 & 230 & 190 \\
\hline 16 & Chlorinity $(\mathrm{mg} / \mathrm{L})$ & & 849 & 802 & 799 & 808 & 883 \\
\hline
\end{tabular}

1-Rasulpara, 2-Jambur, 3-Bhimdeval, 4-Prachi, 5-Umbari,

6- Triveni-Sangam 


\section{RESEARCH ARTICLE}

Table-2b:Physico-Chemical parameters of Shingoda River

\begin{tabular}{|c|c|c|c|c|c|c|c|}
\hline No & .Parameters & 1 & 2 & 3 & 4 & 5 & 6 \\
\hline 1 & Time & $8: 10$ & $8: 41$ & 9:12 & $10: 32$ & $12: 08$ & $2: 04$ \\
\hline & & $\mathrm{am}$ & $\mathrm{am}$ & am & $\mathrm{am}$ & $\mathrm{pm}$ & $\mathrm{pm}$ \\
\hline 2 & Temperature & $21^{\circ} \mathrm{C}$ & $23^{\circ} \mathrm{C}$ & $24^{\circ} \mathrm{C}$ & $25^{\circ} \mathrm{C}$ & $28^{\circ} \mathrm{C}$ & $29^{\circ} \mathrm{C}$ \\
\hline 3 & $\mathrm{pH}$ & 8.99 & 8.01 & 8.93 & 8.43 & 9.03 & 8.9 \\
\hline 4 & $\mathrm{DO}(\mathrm{mg} / \mathrm{L})$ & $4 \cdot 9$ & $5 \cdot 5$ & 6.5 & $5 \cdot 9$ & 3.8 & 6.1 \\
\hline 5 & BOD (mg/L) & 1.65 & 1.45 & 1.5 & 2.05 & 2.2 & 1.65 \\
\hline 6 & $\begin{array}{l}\text { Conductivity } \\
(\mu \mathrm{s} / \mathrm{cm})\end{array}$ & 0.73 & 0.71 & 0.75 & 0.71 & 1.2 & $3 \cdot 5$ \\
\hline 7 & $\mathrm{TS}(\mathrm{mg} / \mathrm{L})$ & 379.8 & 378.8 & 465 & 488.8 & 599.4 & 892.2 \\
\hline 8 & TDS (mg/L) & 333 & 334 & 419 & 444 & 549 & 845 \\
\hline 9 & TSS (mg/L) & 46.8 & 44.8 & 46 & 44.8 & 50.4 & 47.2 \\
\hline 10 & $\begin{array}{l}\text { Water Hardness } \\
(\mathrm{mg} / \mathrm{L})\end{array}$ & 160 & 232 & 280 & 152 & 292 & 408 \\
\hline 11 & $\begin{array}{l}\text { Ca++ Hardness } \\
(\mathrm{mg} / \mathrm{L})\end{array}$ & 52 & 32 & 128 & 56 & 168 & 228 \\
\hline 12 & $\begin{array}{l}\text { Mg+ Hardness } \\
(\mathrm{mg} / \mathrm{L})\end{array}$ & 108 & 200 & 152 & 96 & 124 & 180 \\
\hline 13 & Salinity (mg/L) & 19.78 & 14 & 18.95 & 14.83 & 91.54 & 89.89 \\
\hline 14 & Alkalinity (mg/L) & 750 & 720 & 763 & 767 & 730 & 810 \\
\hline 15 & Acidity (mg/L) & 190 & 210 & 230 & 230 & 199 & 189 \\
\hline 16 & Chlorinity (mg/L) & 799 & 849 & 859 & 843 & 858 & 878 \\
\hline
\end{tabular}

1-Jamvala, 2-Jamjir, 3-Ghantvad, 4-Chhachhar, 5-Kodinar, 6-Mul Dwarka

Table 3(a). Diversity of Zooplankton-Saraswati River

\begin{tabular}{|c|c|c|c|c|c|c|c|c|c|c|}
\hline \multirow[t]{2}{*}{ N. } & \multirow{2}{*}{$\begin{array}{l}\text { Zooplankton } \\
\text { Name of species }\end{array}$} & \multicolumn{5}{|c|}{$\begin{array}{l}\text { Abundance in } \\
\mathrm{no} / \mathrm{ml} \text { of } 6 \text { sites }\end{array}$} & \multicolumn{3}{|c|}{$\begin{array}{l}\text { Rep. by single } \\
\text { genus/species }\end{array}$} & \multirow{2}{*}{$\begin{array}{l}\% \text { of } \\
\text { Diver } \\
\text { sity }\end{array}$} \\
\hline & & 1 & 2 & 3 & 4 & 5 & 6 & Total & AVG & \\
\hline 1 & Temora discaudata & 2 & o & 2 & 1 & 1 & 2 & 8 & 1.33 & 9.41 \\
\hline 2 & Canthocalanus pauper & 1 & 1 & 1 & 1 & 4 & o & 8 & 1.33 & 9.41 \\
\hline 3 & Copepod nauplii & o & 1 & 3 & 3 & o & 3 & 10 & 1.67 & 11.76 \\
\hline 4 & Calanopia minor & 1 & o & o & o & 3 & 2 & 6 & 1.00 & 7.05 \\
\hline 5 & Acrocalanus gracilis & o & 1 & 2 & o & o & o & 3 & 0.50 & $3 \cdot 5^{2}$ \\
\hline 6 & $\begin{array}{l}\text { Pseudodiaptomus } \\
\text { serricaudatus }\end{array}$ & o & 2 & 3 & 2 & 2 & 3 & 12 & 2.00 & 14.11 \\
\hline 7 & Centropages furcatus & 1 & o & 2 & 1 & 1 & 2 & 7 & 1.17 & 8.23 \\
\hline 8 & Calanopia elliptica & 2 & 1 & o & o & 1 & 1 & 5 & 0.83 & 5.88 \\
\hline 9 & Tortanus barbatus & o & o & 1 & 1 & 3 & o & 5 & 0.83 & 5.88 \\
\hline 10 & Tortanus forcipatus & 1 & o & o & o & 1 & 1 & 3 & 0.50 & $3 \cdot 52$ \\
\hline 11 & Keratella tropica & o & 1 & 2 & o & 1 & 2 & 6 & 1.00 & 7.05 \\
\hline 12 & Microcyclops spp. & o & o & 3 & 1 & o & 3 & 7 & 1.17 & 8.23 \\
\hline 13 & $\begin{array}{l}\text { Centropages } \\
\text { tenuiremis }\end{array}$ & 1 & 1 & o & 1 & 1 & 1 & 5 & 0.83 & 5.88 \\
\hline & Total & 9 & 8 & 19 & 11 & 18 & 20 & 85 & 14.17 & \\
\hline
\end{tabular}

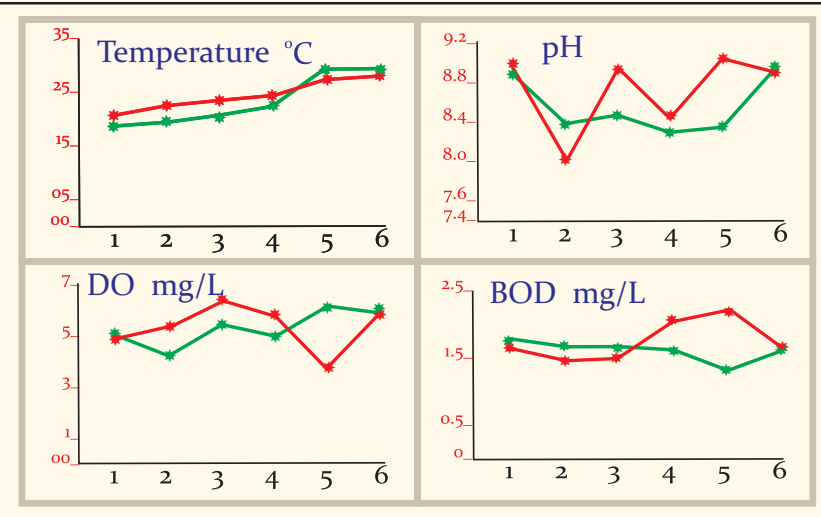

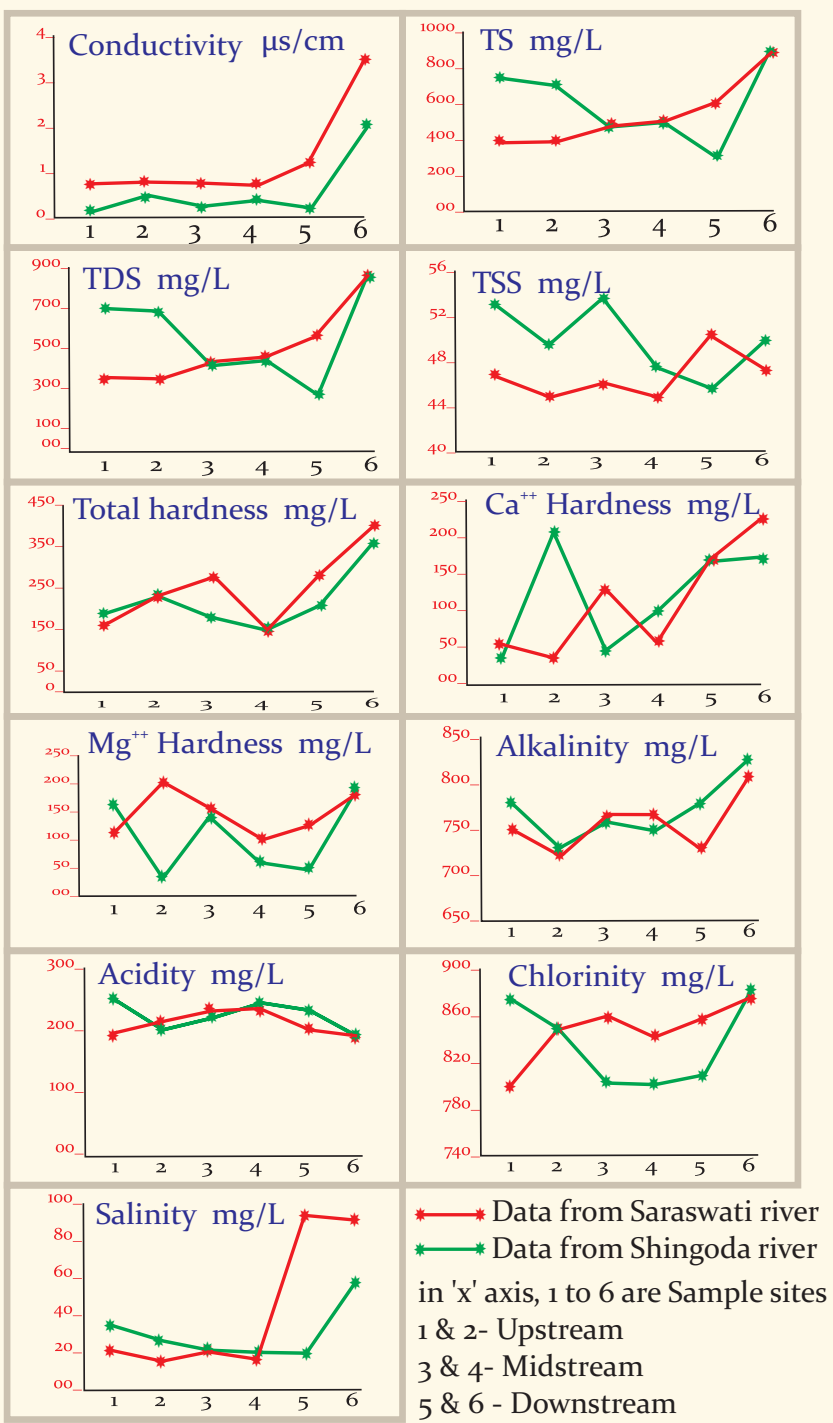

Figure-1: Graphs representing the Comparative Physico-Chemical Parameters of both the rivers, collected from 6 various sites

Table 3(b). Diversity of Zooplankton-Shingoda River

S. Zooplankton Abundance in Rep. by single \% of N. no/ml of 6 sites genus/species Diver \begin{tabular}{llllllllll} 
Name of species & 1 & 2 & 3 & 4 & 5 & 6 & Total & AVG sity \\
\hline
\end{tabular}

\begin{tabular}{llllllllllll}
\hline 1 & Temora discaudata & 1 & 0 & 2 & 1 & 2 & 2 & 8 & 1.34 & 6.77
\end{tabular}

$\begin{array}{lllllllllll}2 & \text { Canthocalanus pauper } 2 & 1 & 0 & 3 & 0 & 3 & 9 & 1.5 & 7.62\end{array}$

$\begin{array}{llllllllllll}3 & \text { P. serricaudatus } & 0 & 0 & 1 & 1 & 1 & 1 & 4 & 0.67 & 3.38\end{array}$

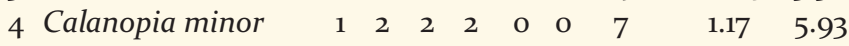

$\begin{array}{llllllllllll}5 & \text { Acrocalanus gracilis } & 2 & 0 & 0 & 1 & 1 & 3 & 7 & & 1.17 & 5.93\end{array}$

$\begin{array}{llllllllllll}6 \text { Copepod nauplii } & 1 & 2 & 3 & 3 & 0 & 1 & 10 & 1.67 & 8.47\end{array}$

$\begin{array}{llllllllllll}7 & \text { Centropages furcatus o } & 0 & 2 & 2 & 1 & 2 & 7 & 1.17 & 5.93\end{array}$

$\begin{array}{lllllllllll}8 & \text { Hyperia galba } & 3 & 0 & 1 & 3 & 0 & 0 & 7 & 1.17 & 5.93\end{array}$

$\begin{array}{llllllllllll}9 & \text { Tortanus barbatus } & 2 & 1 & 3 & 1 & 1 & 2 & 10 & 1.67 & 8.47\end{array}$

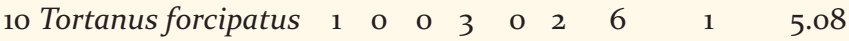

$\begin{array}{lllllllllll}11 & \text { Keratella tropica } & 1 & 0 & 1 & 1 & 1 & 3 & 7 & 1.17 & 5.93\end{array}$

12 Diacyclops spp. $\quad \begin{array}{lllllllllll}0 & 2 & 2 & 2 & 1 & 2 & 9 & 1.5 & 7.62\end{array}$

$\begin{array}{llllllllllll}13 & \text { Microcyclops spp. } & 2 & 1 & 1 & 4 & 0 & 0 & 8 & & 1.34 & 6.77\end{array}$

$\begin{array}{llllllllll}14 & \text { Diaptomus castor } \\ 4 & 2 & 1 & 0 & 0 & 2 & 9 & 1.5 & 7.62\end{array}$

$\begin{array}{lllllllllll}15 & \text { C. tenuiremis } & 2 & 1 & 2 & 2 & 2 & 1 & 10 & 1.67 & 8.47\end{array}$

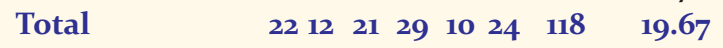



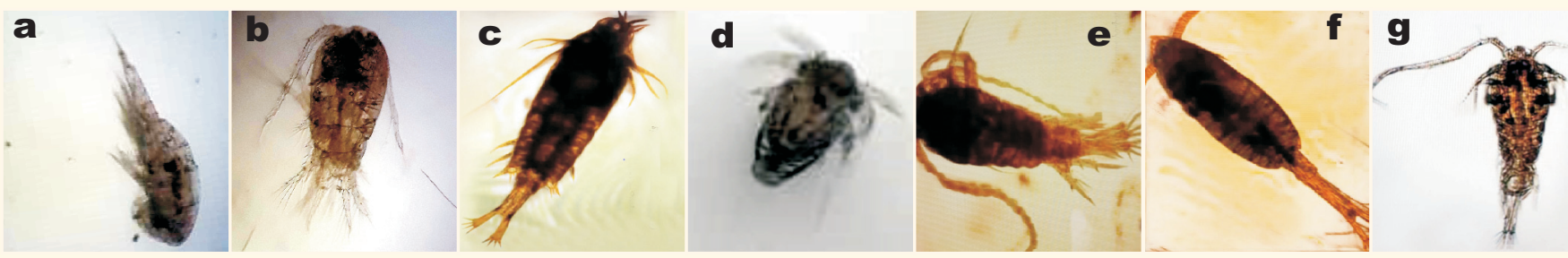

Plate-1: Some Dominant species of zooplanktons; a-Acrocalanus gracilis, b-Calanopia minor, c- Centropages tenuiremis, d-Copepod nauplii, e-Tortanus barbatus, f-Pseudodiaptomus serricaudatus, g-Tortanus forcipatus

The The average $\mathrm{pH}$ of Saraswati River and Shingoda River was recorded 8.55 and 8.71 respectively. The highest $\mathrm{pH}$ was recorded 9.03 at Kodinar (sampling site \# 5 Shingoda River) and lowest was recorded 8.01 at Jamjir Waterfall (sampling site \# 2, Shingoda River).

The average DO of Saraswati River and Shingoda River was recorded $5.36 \mathrm{mg} / \mathrm{L}$ and $5.45 \mathrm{mg} / \mathrm{L}$ respectively. The highest DO was recorded $6.5 \mathrm{mg} / \mathrm{L}$ at Ghantvad (sampling site \#3, Shingoda River) and lowest was recorded $3.8 \mathrm{mg} / \mathrm{L}$ at Kodinar.

The average BOD of Saraswati River and Shingoda River was recorded $1.59 \mathrm{mg} / \mathrm{L}$ and $1.75 \mathrm{mg} / \mathrm{L}$ respectively. The highest BOD was recorded $2.2 \mathrm{mg} / \mathrm{L}$ at Kodinar and lowest was recorded $1.3 \mathrm{mg} / \mathrm{L}$ at Umbari (sampling site \#5, Saraswati River).

The average conductivity of Saraswati River and Shingoda River was recorded $0.54 \mu \mathrm{s} / \mathrm{cm}$ and $1.26 \mu \mathrm{s} / \mathrm{cm}$ respectively. The highest Conductivity was recorded 3.5 $\mu \mathrm{s} / \mathrm{cm}$ at Mul dwarka (sampling site \# 6, Shingoda River) and lowest was recorded $0.11 \mu \mathrm{s} / \mathrm{cm}$ at Rasulpara (sampling site \#1 Saraswati River).

The average TS of Saraswati River and Shingoda River was recorded $594.53 \mathrm{mg} / \mathrm{L}$ and $534 \mathrm{mg} / \mathrm{L}$ respectively. The highest TS was recorded $892.2 \mathrm{mg} / \mathrm{L}$ at Mul dwarka and lowest was recorded at Umbari 295.6.

The average TDS of Saraswati River and Shingoda River was recorded $544.66 \mathrm{mg} / \mathrm{L}$ and $487.33 \mathrm{mg} / \mathrm{L}$ respectively. The highest TDS was recorded $845 \mathrm{mg} / \mathrm{L}$ at Mul Dwarka and lowest was recorded $250 \mathrm{mg} / \mathrm{L}$ at Umbari (sampling site \#5, Saraswati River).

The average TSS of Saraswati River and Shingoda River was recorded $49.93 \mathrm{mg} / \mathrm{L}$ and $46.66 \mathrm{mg} / \mathrm{L}$ respectively. The highest TSS was recorded $53.6 \mathrm{mg} / \mathrm{L}$ at bhimdeval and the lowest was recorded $44.8 \mathrm{mg} / \mathrm{L}$ at Jamjir waterfall \& Chhachhar (sampling site \# 4, Shingoda River).

The average Total Hardness of Saraswati River and Shingoda River was recorded $223.33 \mathrm{mg} / \mathrm{L}$ and $254 \mathrm{mg} / \mathrm{L}$ respectively. The highest Total Hardness was recorded 408 $\mathrm{mg} / \mathrm{L}$ at Mul dwarka and the lowest was recorded $152 \mathrm{mg} / \mathrm{L}$ at Prachi (sampling site \#4, Saraswati River) and Chhachhar.

The average Ca++ Hardness of Saraswati River and Shingoda River was recorded $120 \mathrm{mg} / \mathrm{L}$ and $110.66 \mathrm{mg} / \mathrm{L}$ respectively. The highest $\mathrm{Ca}++$ Hardness was recorded 228 $\mathrm{mg} / \mathrm{L}$ at Mul dwarka and the lowest was recorded $32 \mathrm{mg} / \mathrm{L}$ at Rasulpara \& Jamjirwaterfall.
The average Mg+ Hardness of Saraswati River and Shingoda River was recorded $103.33 \mathrm{mg} / \mathrm{L}$ and $143.33 \mathrm{mg} / \mathrm{L}$ respectively. The highest $\mathrm{Mg}+$ Hardness was recorded 200 $\mathrm{mg} / \mathrm{L}$ at Jamjir waterfall and the lowest was recorded 28 $\mathrm{mg} /$ Lat Jambur (sampling site\#.2, Saraswati River)

The average alkalinity of Saraswati River and Shingoda River was recorded $771.66 \mathrm{mg} / \mathrm{L}$ and $756.66 \mathrm{mg} / \mathrm{L}$ respectively. The highest Alkalinity was recorded $830 \mathrm{mg} / \mathrm{L}$ at Triveni sangam is and the lowest was recorded $720 \mathrm{mg} / \mathrm{L}$ at Jamjirwaterfall.

The average acidity of Saraswati River and Shingoda River was recorded $221.66 \mathrm{mg} / \mathrm{L}$ and $208 \mathrm{mg} / \mathrm{L}$ respectively. The highest acidity was recorded $250 \mathrm{mg} / \mathrm{L}$ at Rasulpara and the lowest was recorded $189 \mathrm{mg} / \mathrm{L}$ at Mul dwarka.

The average Chlorinity of Saraswati River and Shingoda River was recorded $836 \mathrm{mg} / \mathrm{L}$ and $847.66 \mathrm{mg} / \mathrm{L}$ respectively. The highest Chlorinity was recorded $883 \mathrm{mg} / \mathrm{L}$ at Triveni sangam and the lowest was recorded $799 \mathrm{mg} / \mathrm{Lat}$ Prachi \& Jamvala.

The average Salinity of Saraswati River and Shingoda River was recorded $28.81 \mathrm{mg} / \mathrm{L}$ and $41.49 \mathrm{mg} / \mathrm{L}$ respectively. The highest Salinity was recorded $91.54 \mathrm{mg} / \mathrm{L}$ at Kodinar and the lowest was recorded $14 \mathrm{mg} / \mathrm{Lat}$ Jamjir waterfall.

Table 4:Zooplankton diversity in Saraswati and Shingoda Rivers

\begin{tabular}{lll}
\hline Zooplankton Specieses & Saraswati & Shingoda \\
\hline Temora discaudata & ++++ & ++++ \\
Canthocalanus pauper & ++++ & ++++ \\
Copepod nauplii & +++++ & +++++ \\
Calanopia minor & +++ & +++ \\
Acrocalanus gracilis & + & +++ \\
Pseudodiaptomus serricaudatus & ++++++ & ++ \\
Centropages furcatus & +++ & +++ \\
Tortanus barbatus & ++ & +++++ \\
Tortanus forcipatus & + & +++ \\
Keratella tropica & +++ & +++ \\
Microcyclops spp. & +++ & ++++ \\
Centropages tenuiremis & ++ & +++++ \\
Calanopia elliptica & ++ & --- \\
Hyperia galba & ---- & +++ \\
Diacyclops spp. & --- & ++++ \\
Diaptomus castor & ---- & ++++ \\
\hline
\end{tabular}

The study recorded a total of 13 species of zooplankton with a total of 85 individuals (Table-3a).

There were highest 20 individuals of zooplankton recorded at sampling site \#6 (Triveni Sangam) which is the last site of sampling due to high DO. Due to low DO at 


\section{RESEARCH ARTICLE}

sampling site \#2 i.e., Jambur, lowest 8 individuals of zooplanktons were recorded. (Table-3a).

Here, a total of 12 individuals of P.serricaudatus were recorded which was highest with an average of 2 and the percentage of diversity was $14.11 \%$. There are 3 individuals of A.gracilis and 3 individuals of T.forcipatus recorded, which was the lowest of zooplankton species and its average was 0.5. Thus, the percentage of diversity recorded was $3.52 \%$. (Table-3a).

There is a total of 15 species of zooplankton recorded in Shingoda River and a total of 118 individuals was recorded. Highest 29 individuals were recorded at sampling site \#4 i.e., Ghantvad. Lowest of 10 individuals were recorded at sampling site \# 5 i.e., Kodinar. (Table-3b)

Highest 10 individuals of C.nauplii, 10 individuals of T.barbatus and 10 individuals of C.tenuiremis were recorded with an average of 1.67 and the percentage of diversity was $8.47 \%$. Lowest 4 individuals of P.serricaudatus were observed with an average of 0.66 and the percentage of diversity was 3.38\%. (Table-3b, 4).

\section{Conclusion:}

In the present study, it was noted that physicochemical parameters were directly related to planktonic diversity. Growth of zooplankton was correlated with the phytoplankton as because they are the main food source of zooplankton. Their growth depends on the physicochemical parameters. Planktons were important to maintain the ecosystem of the water body and they were bio-indicators of water eco-system. The zooplankton study was carried out to understand its relation with physicochemical parameters. Based on the analysis of physicochemical parameters, the average DO of Shingoda River was recorded slightly higher than the Saraswati River. At Kodinar (sampling site \#5, Shingoda River) BOD and $\mathrm{pH}$ was recorded highest compared to other sampling sites. The study recorded a total of sixteen different species of zooplankton among which 13 species ( 85 individuals) were found in Saraswati River and 15 Species (118 individuals) were found in Shingoda River. The results show that the increasing DO is directly associated with the plankton diversity because zooplankton species diversity is higher in Shingoda River than the Saraswati River. At Kodinar (sampling site $\#_{5}$, Shingoda River) water was not potable and not useful for agricultural purpose and plankton diversity was found low as compare to other sites. Water quality of Shingoda River was better than the Saraswati River except at Kodinar (sampling site \#5).

\section{Acknowledgment:}

We pay our gratitude to Nilesh Gojiya for helping in sample collection and Rx. Krupa Vyas for her support. Cordial thanks to AV Dhara Gareja, Shreya Joshi, Malay Vyas, Jatin Gohil, Shital Bharda, Priyanshi Gondaliya, Deepa Kher, Piyush Amheda for their technical help and companionship. Lastly, AV wants to thank Usha Zala, Savan Tank and Pooja Agravat for their support.
Ambient Science, 2019: Vol. 06(1); 37-41 DOI:10.21276/ambi.2019.06.1.ra06

\section{References:}

Ansari, S. \& Singh, S.K. (2017): Limnological studies with reference to phytoplankton diversity in ponds of semi-arid zone of Western Uttar Pradesh, India. Biol. Forum, 9(2):129147.

Chavda, N.B., Desai, A.Y. \& P.N.C. (2017): Study on zooplankton diversity with physicochemical parameters of Hukal River, Kodinar, Gujarat, India. Int. J. Bioassays, 6.02:5286-5291.

Dave, M.P. \& Chavda, N.B. (2018): A Study on the Relationship among Zooplanktons and Different Abiotic Factors at Barda Bandharan Wetland, Kodinar. Int. I. Res.-Granthaalayah, 6(4):23-35.

Gajbhiye, S.N. \& Desai, B.N. (1981): Zooplankton variability in polluted and unpolluted waters off Bombay. MahasagarBull. Nat. Ins. Oceanogr., 4(3):173-182.

Goswami, A.P. \& Mankodi, P.C. (2012): Study on zooplankton of fresh water reservoir Nyari - II Rajkot district, Gujarat, India. ISCAJ. Biol.Sci., 1(1):30-34.

Kumary Anila K. S. \& Shilly Elizabath David. (2017): Distribution and abundance of phytoplankton in a temple pond. Eur. J. Biomed. Pharm. Sci., 4(8):816-819.

Montes-Ortiz, L., \& Elías-Gutiérrez M. (2018): Faunistic survey of the zooplankton community in an oligotrophic sinkhole, Cenote Azul (Quintana Roo, Mexico), using different sampling methods, and documented with DNA barcodes. $L$. Linmol., 77(3):428-440.

Parikh, A.N., \& Mankodi, P.C. (2012): Limnology of Sama pond, Vadodara City, Gujarat, India. Res. J. Recent Sci., 1(1):16-21.

Rice, E.W., Baird, R.B., Eaton, A.D. \& Clesceri, L.S. (2012): Standard Methods for the Examination of Water and Wastewater, 22nd Edition. Pub. by: American Public Health Association, American Water Works Association, Water Environment Federation. P. 1496.

Roy, K., Gupta, S. \& Nandy, S.K. (2015): Checklist of commonly available phytoplankton and zooplankton genera of urban and rural ponds of Raipur, Chhattisgarh, India. World J. Zool., 10(4):351-357.

Shah, P.L. (2017): District Industrial Potentiality Survay Report Of Gir- Somnath District. Pub. by: MSMEDevelopment Institute Ahmedabad, Gujrat, india. P. 79.

Sharma, K.K., Devi., A., Sharma, A. \& Antal, N. (2013): Zooplankton diversity and physicochemical conditions of a temple pond in Birpur (J and K, India). Int. Res. J. Environ. Sci., 2(5):25-30.

Sharma K.N. \& Mankodi P.C. (2011): Study on plankton diversity of Narmada River, Gujarat. J. Current Sci., 16(1):111-116.

Singh, S. (2015): Analysis of Plankton Diversity and Density with Physico-Chemical Parameters of Open Pond in Town Deeg (Bharatpur) Rajasthan, India. Int. Res. J. Biol. Sci., 4(11):61-69. 